\title{
REFERENCES
}

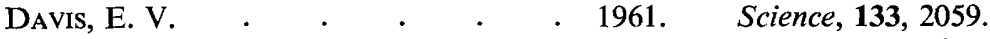

Gledhill, A. W. - . . . . 1959. Br.J. Exp. Path., 40, 291.

Hatch, M. H., AND Stem, R. A. - . 1966. Amer. J. Epidemiol., 84, 495.

Ho, M. . . . . . . 1966. In Interferons, ed. by N. B. Finter,

ISAACS, A. . . . . . . 1963. Adv. Virus Res., 10, 1.

MalluCCI, L. . . . . . . . 1964-65. Arch. ges. Virusforsch., 15, 91.

Parkman, P. D., Meyer, H. M., Kirsch- 1966. New Engl.J. Med., 275, 569. STEIN, RUTH L., AND HoPPS, H. E.

Parks, W. P., Queiroga, Laura T., 1967. Proc. Soc. Exp. Biol. Med., 125, 498. Melnick, J. L., and Pereira, H. G.

WHEELOCK, E. F. $\quad$. $\quad$. $\quad$. 1967.

Zuckerman, A. J., Dunkley, LoRna J., 1968. AND LOVE, G. J.

Zuckerman, A. J., TsiquaYe, K. N., AND 1967. Ibid., 48, 20.

FULTON, F.

\section{LONG-CHAIN MUTANTS OF STREPTOCOCCUS FAECALIS INDUCED BY ULTRAVIOLET IRRADIATION}

\author{
I. LOMINSKI AND M. RAFi SHAIKH \\ Department of Microbiology, The University of Glasgow
}

AMONG the streptococci, which are characterised as a genus by chain formation, the species Streptococcus faecalis is exceptional in forming short aggregates of 4-6 cells or no chains at all. The organism can be made to grow as a chain-forming phenotypic variant in the presence of a number of chemically unrelated compounds of which Suramin (Bayer 205) is the most useful (Lominski, Cameron and Wyllie, 1958). A strain was also found (NCTC 2400) which, although biochemically and serologically identical with $S$. faecalis, grew spontaneously in long chains. Both types of chain are readily broken down by filtrates of ordinary cultures and by lysozyme; lysozyme in turn was found to be powerfully inhibited by Suramin (Lominski and Gray, 1961).

It was assumed as a working hypothesis that separation of bacterial cells is an enzymic process; in the light of this, the enforced formation of chains by chemicals would be due to their inhibitory effect on the cell-separating enzyme, and strains that spontaneously formed long chains would represent enzyme-defective mutants. It seemed possible therefore that ultraviolet irradiation might produce chaining mutants from non-chaining strains.

Two recently isolated strains were used; in 18-hr broth cultures they appeared as single cells or aggregates of 2-4 cocci. Biochemically and serologically they were typical strains of $S$. faecalis.

An overnight fluid broth culture was spun at $2000 \mathrm{~g}$, washed and resuspended in saline to give a density of about $2 \times 10^{9}$ cells per ml; $0.5 \mathrm{ml}$ of the suspension was placed in a sterile, disposable petri dish (Sterilin) and held for periods up to $60 \mathrm{~min}$. at $24 \mathrm{in} .(60 \mathrm{~cm})$ distance from the radiation source (Hanovia 2537 AU, Model II, 12 in., 7 watt, U tube 
with filter). At intervals the suspension was plated out and incubated. Colonies were subcultured into broth and checked for presence of chains.

Ir radiation for $15 \mathrm{~min}$. reduced the number of colonies substantially; $60 \mathrm{~min}$. failed to sterilise the suspension completely and one or two colonies invariably survived. Colonies from the irradiated suspensions initially differed in no way from controls, and fluid cultures obtained from them consisted of single cocci or pairs of cocci. However, when the plates, after initial incubation at $37^{\circ} \mathrm{C}$, were kept at room temperature for $3 \mathrm{wk}$, the colonies from irradiated suspensions became strikingly different from the colonies on the control plates. They grew in size up to $12 \mathrm{~mm}$, and a proportion of them developed daughter colonies. Some developed " outbursting wedges" reminiscent of those described by Shinn (1939). Some of the wedges, growing out several millimetres from the periphery of the colony, showed brush-like protrusions. When subculture was made into broth from the distal ends of the wedges, long-chaining cultures were obtained. Filtrates of short-chain cultures broke down the chains of the mutants, but filtrates of the long-chain cultures were devoid of unchaining ability.

Several long-chain mutants were obtained from each strain in every experiment. All came from suspensions irradiated between 20 and $40 \mathrm{~min}$. in which the percentage kill was well over 90 per cent. Out of several hundred control plates representing well over 50,000 colonies, once only was a colony with a "wedge" observed; subculture from it gave rise to long chains in broth.

One long-chain mutant reverted after $2 \mathrm{mth}$ to the short-chain form, but the remaining mutants have so far proved stable. It is at present impossible to decide whether irradiation selected the long-chain mutants or led to their production, but we believe the latter to be the case. The results we have obtained are in keeping with the hypothesis that the disaggregation of chains of streptococci is due to a specific enzyme activity that may be lost by mutation.

We wish to thank the Rankin Research Fund for a grant towards current expenses of the work.

\title{
REFERENCES
}

Lominski, I., CAMEron, J., AND Wyllie, 1958. Nature, Lond., 181, 1477.

G.

LOMINSKI, I., AND Gray, S. . $\quad$. $\quad$. 1961. Ibid., 192, 683.

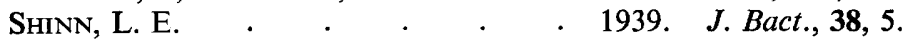

\section{DISSEMINATED CANDIDOSIS FOLLOWING AORTIC VALVE HOMOGRAFT REPLACEMENT AND TRACHEOSTOMY}

\author{
J. G. Ratcliffe* and D. M. Pryce \\ Department of Pathology, St Mary's Hospital Medical School, London
}

\section{Plate XXII}

THE incidence of disseminated candidosis in reported cases is limited almost entirely to the period following the introduction of antibiotics, chemotherapy and adrenal hormones (Zimmerman, 1955; Keye and Magee, 1956; Louria, Stiff and Bennett, 1962; Symmers, 1964). The diagnosis is often difficult since the significance of a finding of candida in blood,

* Present address: Department of Chemical Pathology, St Bartholomew's Hospital, London, E.C.1. Received 4 Mar. 1968; accepted 18 Apr. 1968. 